\title{
DNA Barcoding of Mammals in Mexico: Implications for Biodiversity
}

\author{
Sergio Ticul Álvarez-Castañeda ${ }^{*}, 1$, Consuelo Lorenzo ${ }^{2}$, Evelyn Rios ${ }^{1}$, Patricia Cortés-Calva ${ }^{1}$, \\ Manuel Elías ${ }^{3}$, Jorge Ortega ${ }^{4}$, and Fernando A. Cervantes ${ }^{5}$
}

\author{
${ }^{1}$ Centro de Investigaciones Biológicas del Noroeste, La Paz, Baja California Sur, México \\ ${ }^{2}$ El Colegio de la Frontera Sur, San Cristóbal de Las Casas, Chiapas, México \\ ${ }^{3}$ El Colegio de la Frontera Sur, Chetumal, Quintana Roo, Mexico \\ ${ }^{4}$ Escuela Nacional de Ciencias Biológicas, Posgrado Químico-biológicas, Instituto Politécnico Nacional, Distrito \\ Federal, México \\ ${ }^{5}$ Instituto de Biología, Universidad Nacional Autónoma de México, Distrito Federal, México
}

\begin{abstract}
The Mexican Barcode of Life (MEXBOL) project started as an initiative by researchers who wanted México to join the international DNA barcoding (iBOL) collaboration to establish a genetic system of species identification and discovery. MEXBOL has three main nodes associated with different research institutions in the northern, central, and southern parts of the country. At the beginning of 2009, the laboratories of the three nodes began to operate with support from the University of Guelph in Canada where DNA barcoding began in 2003. By the end of 2011, the laboratories in México will be completely equipped and fully operational. The project is funded by the Consejo Nacional de Ciencia y Tecnología (CONACyT). In addition, the steering committee of MEXBOL supports the Comisión Nacional para el Conocimiento y Uso de la Biodiversidad (CONABIO) initiative to offer grants to any university and research center for barcoding collections of Mexican specimens. We present preliminary results of projects dealing with barcoding Mexican mammals. The aims of these analyses are to evaluate the importance of the DNA barcoding (using cytochrome $c$ oxidase subunit I gene; COI) for the identification of species, study of genetic diversity, and taxonomic review. Our preliminary data suggest that DNA barcodes can be used for the discovery of cryptic species and have important implications to the understanding of the mega-diversity of mammals in México.
\end{abstract}

Keywords: Chaetodipus, Cytochrome C oxidase subunit I, Cryptic biodiversity, Heteromyidae, Heteromys, MEXBOL, Species diversity.

\section{INTRODUCTION}

México is one of the mega-diverse countries of the world $[1,2]$. Part of the biological richness of this region is the endemic species in many biological groups, such as plants, invertebrates, fish, and mammals. For vertebrates other than fish, $32 \%$ of the 2,500 species known are endemic. In recent years, studies using genetic data (DNA sequences) have shown the existence of Mexican cryptic species accentuating the importance of continued reassessment of cryptic biodiversity. For example, in a study analyzing DNA sequences (nuclear and mitochondrial genes) combined with morphological data of fish from Mexico's Reserva de la Biósfera del Alto Golfo de California y Delta del Río Colorado, was discovered the second fish species endemic to the river's delta, the Delta Mudsucker (Gillichthys detrusus). This species was erroneously placed in the synonymy of $G$. mirabilis in 1907 and had since remained unrecognized until 2011 [3]. In the endemic Mexican pocket gopher Cratogeomys merriami a study revealed three major genetic

*Address correspondence to this author at the Centro de Investigaciones Biológicas del Noroeste, La Paz, Baja California Sur, México; Tel: +52 612 123 8486; Fax: +52 612125 3625; E-mail: sticul@cibnor.mx and morphological clades within the species. Here, $C$. perotensis, C. fulvescens, and C. merriami were recognized for central Mexico [4]. Given the foregoing, DNA barcoding represents an application to the study of biodiversity [5] and the discovery of cryptic species. In México, an organization was created to establish a genetic identification system for the plants and animals, The Mexican Barcode of Life (MEXBOL). This is linked directly to the International Barcode of Life (iBOL) project. Additionally, MEXBOL is part of a network supported directly by the Consejo Nacional de Ciencia y Tecnología (CONACyT) and received the first installment of funding in March 2009. Funds to support barcoding and a mirror site for the Barcode of Life Database (BOLD) have also been provided by the Comisión Nacional para el Conocimiento y Uso de la Biodiversidad (CONABIO).

The goal of MEXBOL is to operate a National Laboratory system with three nodes situated at institutions in the northern, southern and central parts of México: 1) Centro de Investigaciones Biológicas del Noroeste (CIBNOR), 2) El Colegio de la Frontera Sur (ECOSUR); both of which are research centers of the Federal Government under CONACyT, and 3) Universidad Nacional Autónoma de 
México through the Instituto de Biología. We are aiming for a capacity of about 15,000 reactions per year at each node for the extraction of DNA, PCR amplification, and sequencing of nucleotides. When fully operational, we will seek additional support from other Mexican biorepositories to speed the inventorying of biodiversity in México, and to increase the collaboration with Mesoamerican researchers. In adition, CONABIO has financed 20 projects on DNA barcoding to support researchers at 12 Mexican institutions (see http://www.conabio.gob.mx/institucion/proyectos/doctos/ pdf/selecc_CB09.pdf).

The most relevant aspects of this project are: a) establishing México in a leading international role in taxonomic identification and systematic study; b) creating facilities for the cryopreservation of tissues and DNA extracts that are associated with voucher specimens housed in public institutions; and c) establishing a bioinformatics platform to be used for the generation, storage and management of sequences and associated curatorial data that will be diseminated through the internet.

The main scientific and tecnological benefits that MEXBOL will provide are: 1) a genetic methodology for the biodiversity inventory of México; 2) a database with an algorithm for automatic identification of submitted sequences; 3) molecular taxonomic tools to aid in the description of new species; and 4) development of alliances and synergies to reduce the laboratory costs for sequencing and achieving faster identifications of the eukaryotic species of the world.

We consider DNA barcoding as one of the components of the toolkit used for taxonomic identification and as an additional character set that should be combined with morphological methods to delimit species and their evolutionary relationships. However, DNA barcodes should be associated with voucher specimens that have been identified by taxonomic experts.

Mammals have one of the best known taxonomic classifications [6]. However, some species are still not clearly understood because there is variation in their diagnostic features, such as morphology of the skull [7-9]. Molecular tools are an option that can be used in addition to morphology to help get a better understanding of the species diversity in mammals and their phylogenetic relationships [10-12]. However, some recent phylogenetic studies using molecular tools have conflicted with traditional morphologically derived phylogenies [7-9]. The development of DNA barcoding as a genetic reference system for species identification is a strong effort to bridge this technological gap by using standardized sequences with associated voucher specimens. For example, comparison of verified voucher specimens with recently collected small mammals from Suriname indicated several differences between field identifications and species determinations [11]. Based on initial analyses of DNA barcodes in México, there is not a wide use of these techniques for taxonomy, but many studies are using molecular techniques for systematic studies [7-9, 13, 14].

In México, many of the previous phylogenetic studies of mammals have been done mainly with the cytochrome $b$ or the cytochrome $c$ oxidase subunit III genes. However at the moment, with the implemantation of the MEXBOL project, the cytochrome $c$ oxidase subunit I (COI) is now the most represented and sequenced gene among Mexican mammal species. However, we think that where possible, COI should be combined with other genes, nuclear or mitochondrial, for a robust systematic study.

Herein, we present two case studies demonstrating the utility of DNA barcoding on Mexican mammals including an investigation of species groups in Chaetodipus arenarius (Heteromyidae: Rodentia) from throughout its distributional range, including type localities, which was developed at the Centro de Investigaciones Biológicas del Noroeste, and an analysis of species diversity within the genus Heteromys (Heteromyidae: Rodentia), which was developed at El Colegio de la Frontera Sur.

The pocket mouse, Chaetodipus arenarius, was formally recognized as a unique species endemic to the Baja California Peninsula of México [15-19] with 12 subspecies [20] and $C$. dalquesti [17] as a junior synonym of $C$. $a$. arenarius. However, recent molecular and morphological analyses proposed that this taxon should be considered a species complex composed of $C$. arenarius, $C$. dalquesti and C. siccus [21]. Here, we focused on obtaining barcodes of the three putative species with distribution in the Baja California Peninsula to test the utility of DNA barcoding to identify species similar in morphology. The study also aimed to use COI gene sequences to hypothesize the phylogenetic relationships of the Chaetodipus arenarius complex.

The genus Heteromys has had many taxonomic changes in the last few years, including the description of several new species [22-25]. In México, three species have been recorded: 1) $H$. desmarestianus is a polytypic species with distribution restricted to the southern states of Veracruz, Tabasco, Oaxaca, Chiapas and the Yucatan Peninsula to 2,400 $\mathrm{m}$ above sea level [26]. Some studies indicate that $H$. desmarestianus represents a complex of several externally similar species, but with considerable variation in their karyotypes, allozyme and cranial morphology [25, 27]. This species comprises 12 subspecies, of which three are distributed in México; $H$. d. desmarestianus, $H$. d. goldmani and $H$. d. temporalis [6]. Rogers and Schmidly [27] considered $\mathrm{H}$. goldmani (distributed in southeastern Chiapas and southwestern Guatemala to $2,000 \mathrm{~m}$ above sea level) to be different from $H$. desmarestianus based on cranial variation and baculum morphology. However, later allozyme analysis found no differences between the two taxa and $H$. goldmani was again considered as a subspecies of $H$. desmarestianus [28]. Nevertheless, some authorities still consider $H$. goldmani as a different species [26]. 2) $H$. nelsoni, a monotypic species, is known by only a few specimens from Cerro Mozotal, in Chiapas, and Volcán Tajumulco, in Guatemala [26]. It has been documented at high elevations $(2,500$ to $2,800 \mathrm{~m}$ above sea level [26, 29, $30]$ ) and is not sympatric with $H$. d. goldmani, which is found at lower elevations [31]. It is listed as critically endangered by the International Union for Conservation of Nature [32], and receives special protection by the Mexican Government [33]. A third population not previously known was registered in Chiapas in January of 2009 [34]. 3) $H$. 
gaumeri, a monotypic species, has a distribution restricted to deciduous forests of the Yucatan Peninsula to $100 \mathrm{~m}$ above sea level. This species can be very similar in color to $H$. desmarestianus in sympatric areas [26]. It may represent an ancient lineage of Heteromys and was removed from the desmarestianus group and placed in its own group [35].

\section{MATERIALS AND METHODS}

The specimens of Chaetodipus arenarius were DNA barcoded and analyzed with $C$. baileyi, $C$. rudinoris and $C$. spinatus as outgroups (Appendix 1). Heteromys was barcoded and analyzed with Liomys pictus and L. salvini as outgroups (Appendix 2). Total genomic DNA was extracted using the standard rapid salt-extraction protocol [36]. The 5' fragment of the mitochondrial COI gene ( 640 bp) was amplified using the universal primer cocktail for DNA barcoding [37]. All polymerase chain reactions (PCR)

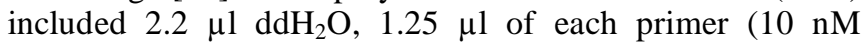
concentration), $0.237 \mu \mathrm{l}(0.4 \mathrm{nM}) \mathrm{dNTPs}, 0.25 \mu \mathrm{l}(3 \mathrm{mM})$ $\mathrm{MgCl}_{2}, 0.0625 \mu \mathrm{T}$ Taq polymerase (platinum, Invitrogen, Carlsbad, CA), and $1 \times$ Taq buffer to a final volume of 12.5 $\mu 1$.

Non-redundant haplotypes were identified using the Collapse ver. 1.1. [38], and TCS ver. 1.18 [39] software. The model comparison software MrModeltest ver. 2.2 [40] with the Akaike Information Criterion (AIC) was used to select the most appropriate model of nucleotide substitution. Maximum-likehood (ML), maximum-parsimony (MP), using an heuristric procedure with 10 random sequence additions and tree bisection reconnection (TBR) branch swapping, and neighbor-joining using Kimura 2-parameter model (K2P) and The General Time Reversible model (GTR) were conducted in PAUP ver. 4.0b10 software [41]. Support for nodes was assessed with bootstrap analyses of 1,000 replicates. A Bayesian inference analysis (BI) was performed using MrBayes ver. 3.0b4 software [42]. A consensus tree was generated with the $50 \%$ majority-rule algorithm. For Chaetodipus arenarius, a minimum spanning network, Fu's $F$ test, network construction (using the parsimony algorithm), haplotype diversity, and nuclear diversity were performed with ARLEQUIN version 2.0 [43], to contrast the genetic parameters among species.

\section{RESULTS}

There were 42 unique haplotypes identified in the $640 \mathrm{bp}$ fragment of COI sequenced for Chaetodipus. The four phylogenetic analyses converged on essentially identical tree topologies obtained in a previous study that concatenated the Cyt $b$ and COIII genes [21]. There were three monophyletic clades, each with $100 \%$ support, representing C. arenarius, C. siccus, and C. dalquesti (Fig. 1). The maximum parsimony analysis yielded 4,392 trees (length $=430, \mathrm{CI}=$ $0.672, \mathrm{RI}=0.925)$. The maximum likelihood analysis with the GTR + I + G evolution model $(\mathrm{A}=0.310, \mathrm{C}=0.223, \mathrm{G}=$ 0.117 , and $\mathrm{T}=0.348)$, invariable sites $=0.632$, and gamma distribution $=2.921$ ) produced one tree $($ score $=7589.0$, Fig. 1b). The average interspecific sequence divergence (K2P) ranged from $5.8 \%$ between $C$. dalquesti and $C$. siccus to $15.8 \%$ between $C$. arenarius and $C$. dalquesti (Table 1). The average intraspecific sequence divergence ranged from $0.6 \%$ for $C$. siccus to $2 \%$ for $C$. arenarius.

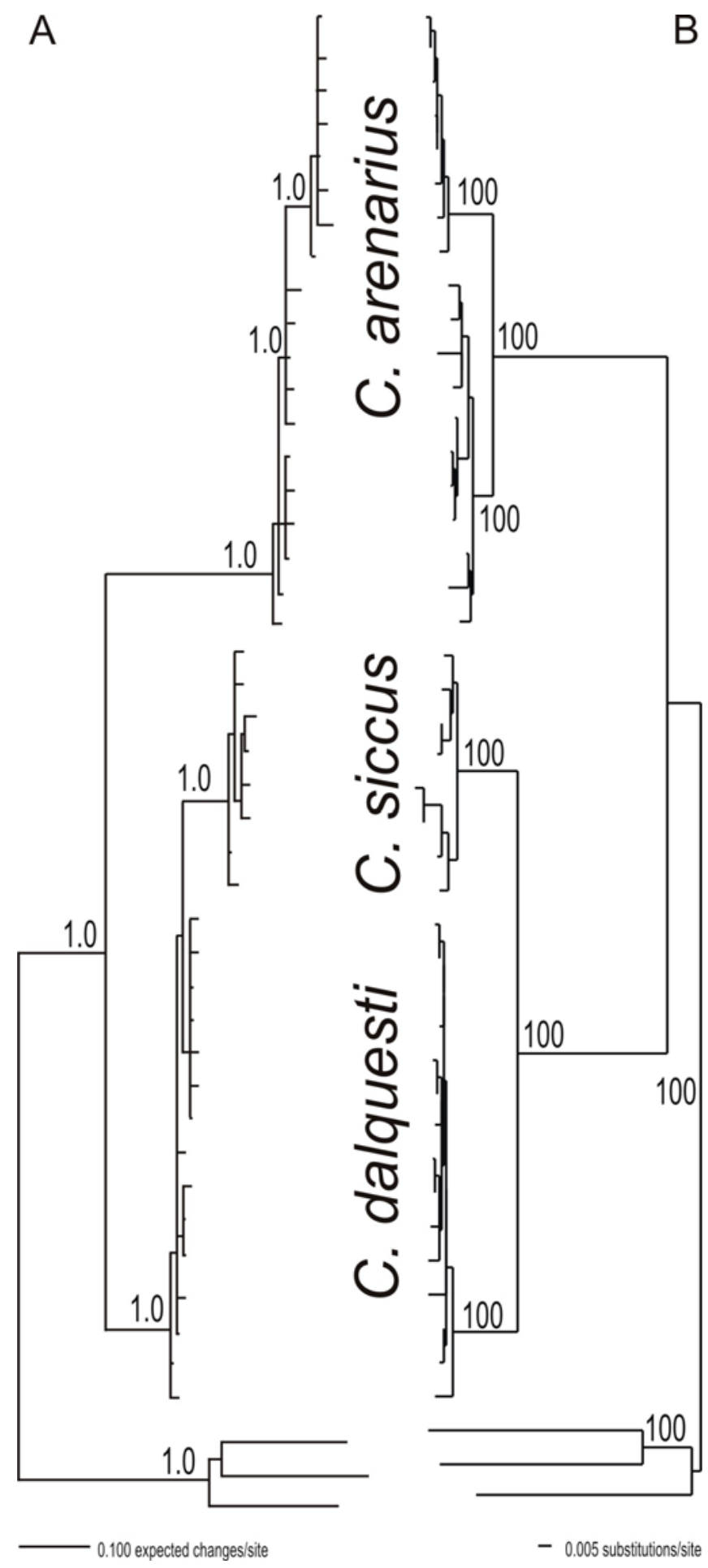

Fig. (1). Phylogenetic relationships among 42 haplotypes of the COI gene sequences of the Chaetodipus arenarius complex. The topology was the same for maximum parsimony, neighbor-joining, maximum likelihood, and Bayesian inference analyses. Three groups are monophyletic representing $C$. arenarius, $C$. siccus, and C. dalquesti. C. baileyi, C. rudinoris, and C. spinatus were used as outgroup. (A) Bayesian inference, and (B) neighbor-joining analyses. The values at the nodes are branch support. 
Table 1. Average Genetic Distances (Minimum-maximum) between Chaetodipus arenarius, C. dalquesti, and $C$. siccus. Under the Evolutionary Model Most Appropriate for the Dataset, General Time Reversible (GTR, below Diagonal) and Kimura 2 Parameter (K2P, above Diagonal).

\begin{tabular}{|l|c|c|c|}
\hline & $\mathbf{1}$ & $\mathbf{2}$ & $\mathbf{3}$ \\
\hline \hline 1) C. arenarius & $2.00(0.15-3.92)$ & $15.82(14.54-17.23)$ & $15.72(14.64-17.23)$ \\
\hline 2) C. dalquesti & $15.37(14.17-16.72)$ & $0.95(0.15-1.55)$ & $5.81(5.10-6.96)$ \\
\hline 3) . siccus & $15.27(14.27-16.58)$ & $5.76(5.06-6.88)$ & $0.63(0-1.54)$ \\
\hline
\end{tabular}

In the minimum spanning network only one haplotype was present in two different type localities (H34; Migriño and La Paz), representing the subspecies $C$. d. dalquesti and C. d. sublucidus, respectively. Using maximum parsimonious connections (27 steps, $P>0.95$ ), three disjointed networks were obtained: $C$. arenarius, $C$. dalquesti, and $C$. siccus. These were separated by a minimum of 79 and 32 mutational steps, respectively (Fig. 2), well beyond the confidence limits for parsimony. The genetics parameters are presented in Table $\mathbf{2}$.

The C. arenarius network (19 haplotypes) covers a large geographic area of the peninsula and includes seven type localities. Specimens of C. a. ambiguus (type locality Yubay, 30 mi SE Calamahué, Baja California) and C. a. mexicalis (type locality Los Muertos Canyon Fan, $32^{\circ} 27^{\prime} \mathrm{N}, 115^{\circ} 53^{\prime}$ W, Gaskill’s Tank, near Laguna Salada, Baja California) were not collected. No haplotype was found to be widespread among the type localities. The average distance among the localities is $430 \pm 242 \mathrm{~km}(120-880 \mathrm{~km})$. There are two sub-networks representing the northern and southern Peninsula separated by the Vizcaino Desert that has more mutational steps than the minimum spanning network obtained from Cyt $b$ [21], but these differences are not significant $(P<0.05)$.
The C. dalquesti network (15 haplotypes) covers a moderate geographic area of the southern part of the peninsula and includes three type localities. No haplotype was found to be widespread among the type localities and there was a star-like pattern indicating a recent expansion.

The C. siccus network (8 haplotypes) covers a small geographic area on Cerralvo Island in the southern part of the peninsula, and includes only one type locality. There were no sub-networks found but there was a star-like pattern with few mutational steps between haplotypes (Fig. 2).

For the $640 \mathrm{bp}$ COI fragment of Heteromys, the average base composition was $\mathrm{A}=27.1 \%, \mathrm{C}=22.8 \%, \mathrm{G}=17.1 \%$, and $\mathrm{T}=32.9 \%$. There were $162(24.6 \%)$ polymorphic sites of $128(19.4 \%)$ transitions, and $52(7.9 \%)$ transversions, and 13 unique haplotypes were identified. Gene diversity ( $h$; mean $\pm S D$ ) was $0.8968 \pm 0.0302$, nucleotide diversity was $0.060176 \pm 0.0298$, and the mean number of pairwise differences was $39.5956 \pm 17.6784$.

The maximum parsimony analysis yielded three trees (length $=718, \mathrm{CI}=0.937, \mathrm{RI}=0.971, \mathrm{RC}=0.910$ ). The maximum likelihood analysis with the GTR evolution model $($ Base $=0.26580 .23860 .1696) ;$ Nst $=6 ;$ Rmat $=8.9586$ 14.89968 .71530 .9262 32.6384; Rates = equal; Pinvar = 0; $\mathrm{K}=8, \mathrm{AIC}=6123.345)$ produced one tree $($ score $=$

\section{A) Chaetodipus arenarius}

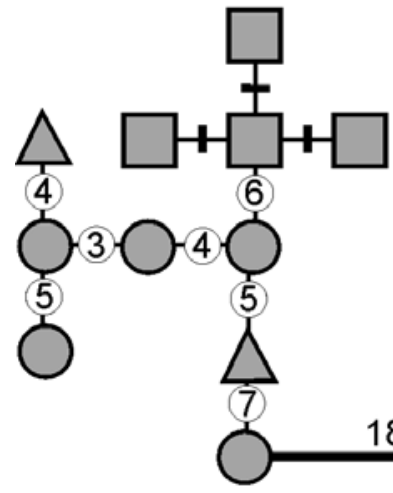

South peninsula
B) Chaetodipus dalquesti

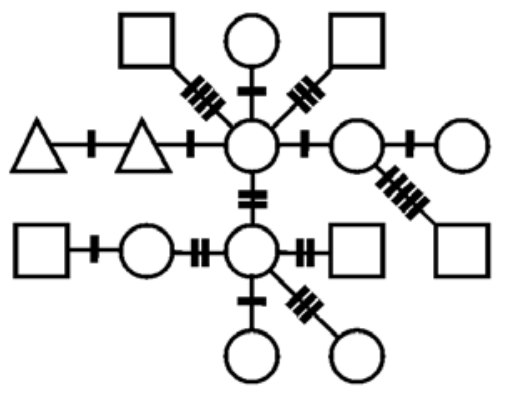

C) Chaetodipus siccus

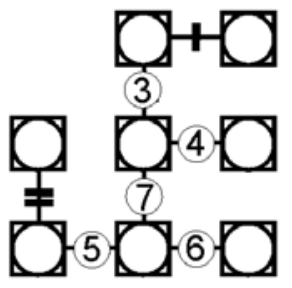

Fig. (2). The minimum spanning network for the COI data set of Chaetodipus from the Baja California Peninsula. Each perpendicular hash mark across the line or number within the circle between adjacent haplotypes in the network represents a single-base substitution. A) The minimum spanning network of $C$. arenarius has two sub-networks: northern peninsula and southern peninsula (Magdalena Island, grey triangle; San Jorge, grey circle; El Mogote, grey square; San Quintin, solid square; Guerrero Negro, solid circle; El Barril, solid right triangle; and San Felipe, solid left triangle). B) The minimum spanning network of $C$. dalquesti: La Paz, circle; Margarita Island, square; and Migriño, triangle. C) The minimum spanning network of $C$. siccus. All the specimens are from Cerralvo Island. 
3053.672; Fig. 3a). It had a similar topology to the Bayesian tree (Fig. 3b) and also to the maximum parsimony and neighbor joining trees (not shown). All phylogenetic analyses recovered the three recognized species of $H$. nelsoni, $H$. gaumeri, and $H$. desmarestianus as deeply divergent and strongly supported clades.
Heteromys nelsoni had only two haplotypes that differed by four transitional mutations indicating relatively minimal genetic variability in this species. In $H$. gaumeri, four haplotypes were defined with a maximum of six mutations between haplotypes. $H$. desmarestianus had two subclades (Fig. 3) representing the subspecies, $H$. $d$. desmarestianus

Table 2. Molecular Diversity Indices (With Standard Deviations Where Appropriate for Subspecies of Chaetodipus species from Localities in Baja California and Baja California Sur. Sample Size (n), Number of Haplotypes (k), Haplotypic or Nei's Diversity $(h)$, Pairwise Differences (PW), Nucleotide Diversity $(\pi)$, Tajima's D, and Fu's $F$ Test

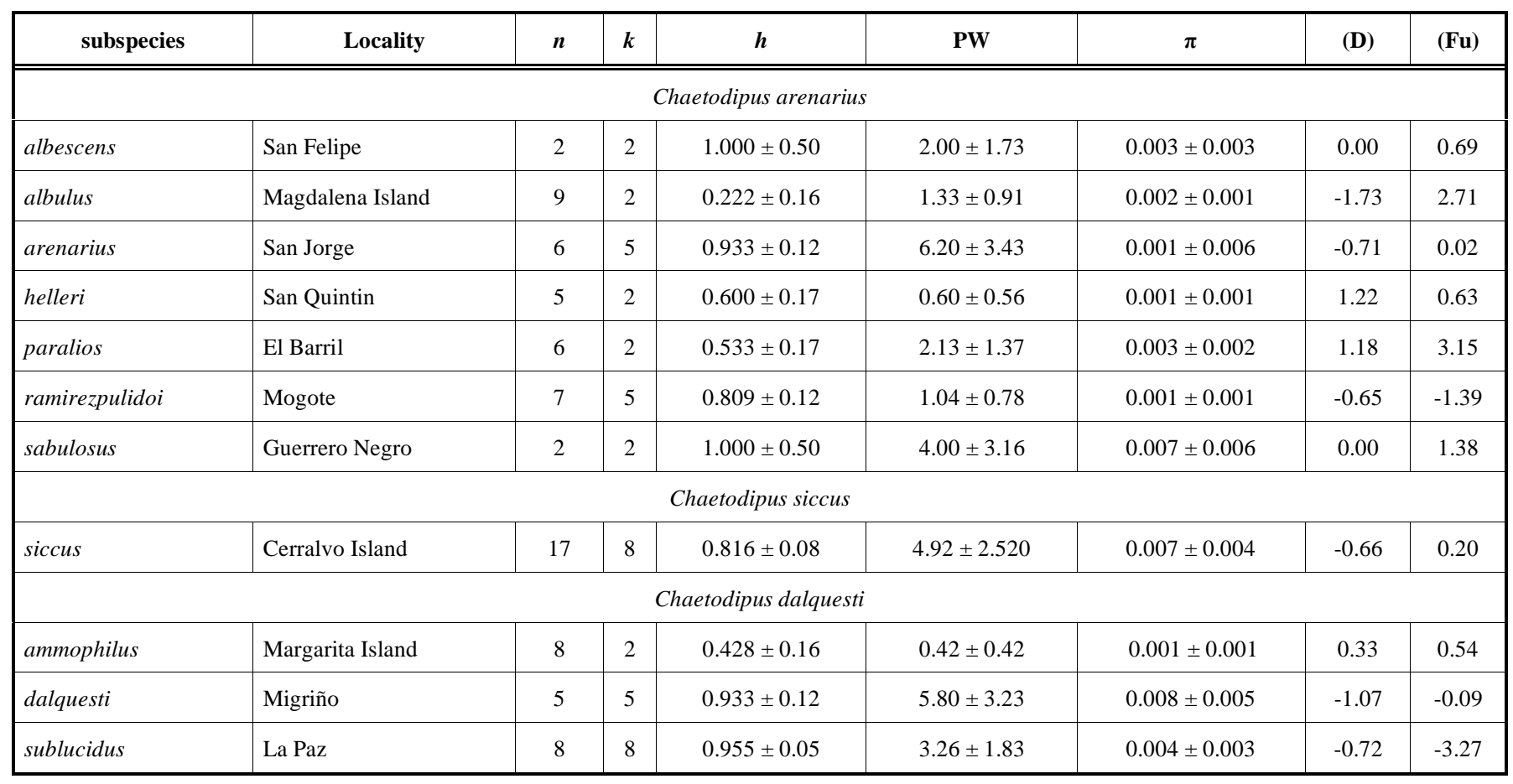

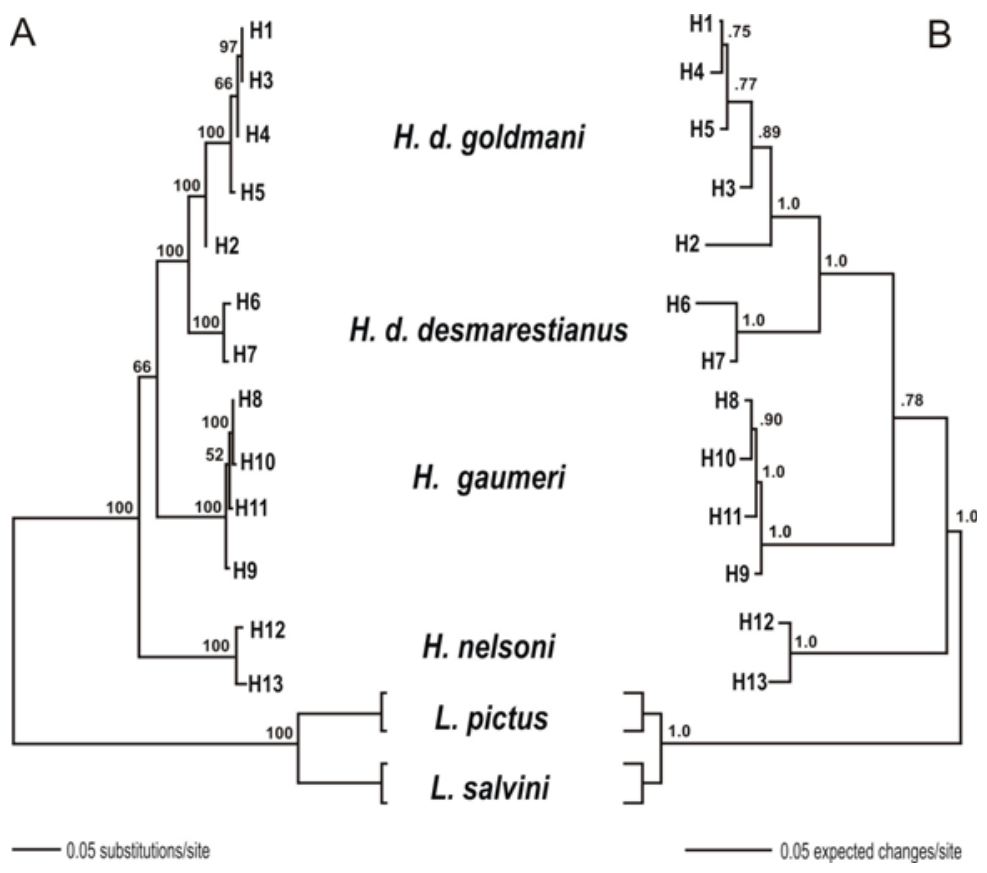

Fig. (3). Phylogenetic relationships between the species of Heteromys based on analysis of COI sequence variation. Branch support values are indicated on the tree. The genus Liomys was used as outgroup. (A) Maximum-likelihood and (B) Bayesian inference trees. 
with two haplotypes, and $H$. $d$. goldmani in southeastern Chiapas with five haplotypes. The average genetic distance (K2P) among the species of Heteromys was between $13.1 \%$ and $18.6 \%$. The distance between $H$. d. desmarestianus and H. d. goldmani was $8.1 \%$, and for H. gaumeri and H. nelsoni was $18.6 \%$. The average intraspecific divergence ranged from $0.4 \%$ for $H$. nelsoni to $1.5 \%$ for $H$. $d$. goldmani (Table 3).

\section{DISCUSSION}

For Chaetodipus from the Baja California Peninsula, the average K2P genetic distances of COI found among clades (5.8\% to $15.8 \%)$ were higher than suggested by the genetic species concept for average sister species differences based on mitochondrial cytochrome $b$ gene [44]. In addition, the three groups are monophyletic following the phylogenetic species concept [45] suggesting that $C$. arenarius, $C$. dalquesti, and $C$. siccus warrant species recognition, as previously suggested [21]. Within C. arenarius, there is a phylogeographic break (3.22\% sequence divergence) that corresponds to the southern and northern peninsula separated at the Vizcaino Desert, as also indicated by cytochrome $b$ data [21].

For Heteromys from México, the molecular analysis of DNA barcodes showed three well-supported monophyletic groups with low variation within $H$. nelsoni and $H$. gaumeri, but high variation within $H$. desmarestianus. The genetic distance within $H$. desmarestianus (8.3\%) was similar to the range of values based on cytochrome $b$ previously reported (8.0\% to 9.2\%) [35]. These authors considered $H$. desmarestianus and H. goldmani as separate species. They are allopatrically distributed and separated by the physical barrier of the Sierra Madre de Chiapas mountain chain. Their distinction had been supported by morphologic and morphometric analyses in Chiapas, where the populations of the southeast $(H . d$. goldmani) were different from the populations of the north $(H . d$. desmarestianus) [35]. Since $H$. goldmani has also been accepted by other studies based on karyotype, allozyme, morphological, cytochrome $b$, and nuclear genes analyses $[35,46]$, we conclude that COI data is further support of it as a valid species. Thus, there are four species of Heteromys distributed in southeastern México: $H$. desmarestianus, H. gaumeri, H. goldmani, and H. nelsoni.

Although our phylogenetic analysis of COI sequences did not include $H$. anomalus and $H$. australis, $H$. nelsoni is basal in relation to the other species, which is concordant with previous analysis of sequences of cytochrome $b$ and nuclear genes [35]. The specimens of the newly discovered population in Chiapas from La Cascada to Cerro Mozotal $(2,850 \mathrm{~m})$ were grouped within the species $H$. nelsoni according to diagnostic morphological characters of the species and the barcodes obtained in this study. Within $H$. gaumeri, our data did not show strong geographic structure. Samples from Yucatán and Campeche had haplotypes that were shared; however, the only haplotype from Quintana Roo was in a basal branch.

The influence of environmental factors associated with vegetation types is an important factor that probably acted upon the diversification and speciation process of species with wider distribution and varied habitat, such as $H$. desmarestianus and $C$. arenarius. In contrast, species with restricted distribution, such as $H$. nelsoni and C. siccus, have low genetic variation. Genetic drift within these populations may have resulted in reduced genetic variability, which indicates that the species are vulnerable to extinction. In this regard, recognition and management of conservation units below the species level are crucial to avoid loss of genetic diversity in these species.

It is also necessary to continue with studies focused on estimating the levels of genetic variability in mammals from throughout their distribution with the additional aim of investigating the phylogenetic and taxonomic status in tropical habitats. This will help in proposing conservation policies for species associated with these habitats in southeastern México. In addition, this region needs to be surveyed with more attention to detail concerning the microhabitat of each species. These analyses demonstrate the ability of DNA barcoding to discriminate cryptic species and the amount of variation that an endemic and restricted species can have within its distributional area.

\section{ACKNOWLEDGMENTS}

We thank the lab and field assistance provided by D. Navarrete, J. A. Vargas, A. Romero-Meza, and A. Hernández-Dávila at the Instituto Politécnico Nacional and Universidad Autónoma de Campeche, M. De la Paz Cuevas and A. Gutiérrez-Ramos at Centro de Investigaciones Biológicas del Noroeste, J. Bolaños, J. López and J. Espinoza at El Colegio de la Frontera Sur, and Y. HortelanoMoncada and J. Vargas-Cuenca at Instituto de Biología, UNAM. Financial support was generously provided to STAC by CONACYT grant I25251N; 39467Q; SEMARNAT-2002-CO1-019, CONABIO HB27, to CL by Project CONACyT-SEP 80461, to PCC by CONABIO

Table 3. Average Genetic Distances (Minimum-maximumn) between Heteromys desmarestianus goldmani, H. d. desmarestianus, H. gaumeri, and H. nelsoni, Under the Evolutionary Model Most Appropriate for the Dataset, General Time Reversible (GTR, below Diagonal) and Kimura 2 Parameter (K2P, above Diagonal)

\begin{tabular}{|l|c|c|c|c|}
\hline & $\mathbf{1}$ & $\mathbf{2}$ & $\mathbf{3}$ & $\mathbf{4}$ \\
\hline \hline 1) H.d.goldmani & $1.46(0.15-3.19)$ & $8.19(6.44-9.43)$ & $15.84(10.32-18.45)$ & $18.24(15.45-19.67)$ \\
\hline 2) H.d. desmarestianus & $8.30(6.57-9.55)$ & $1.09(1.09-1.09)$ & $13.14(12.20-14.10)$ & $16.43(15.08-17.63)$ \\
\hline 3) H. gaumeri & $16.34(10.51-19.27)$ & $13.32(12.39-14.28)$ & $0.66(0.46-1.07)$ & $18.64(17.26-20.14)$ \\
\hline 4) H. nelsoni & $19.08(16.58-20.34)$ & $17.43(16.33-18.37)$ & $19.16(17.74-20.69)$ & $0.41(0.41-0.41)$ \\
\hline
\end{tabular}


HB005, to JO by CONACyT 95900 and IPN-20100165, and to FCR by CONABIO HB29. We are grateful to CIB, CNMA, ECOSUR-Chetumal, ECOSUR-San Cristóbal de Las Casas, ENCB, INECOL, MZFC-UNAM, UAC, and UADY for supplying museum tissue samples and the examination of voucher specimens. This is part of the Mexican Barcode of Life (MEXBOL) contribution. We are indebted to B. Lim for advice and comments on this manuscript.

\section{APPENDIX 1}

Specimens examined of Chaetodipus including localities (type locality indicated with an asterisk) with latitude and longitude, haplotype number (catalog and GenBank accession numbers in parentheses) in the mammal collection of the Centro de Investigaciones Biológicas del Noroeste (CIB). Chaetodipus arenarius: C. a. albescens (San Felipe, Baja California*). San Felipe (31.022778 N, 114.841611 W), haplotype 1 (2903, HQ690033), haplotype 2 (2904, HQ690034). C. a. helleri (San Quintin, Baja California*). San Quintin (30.348333 N, -115.818333 W). Haplotype 3 (6803, 6804, 6807, HQ690035), haplotype 4 (6805, HQ690036). C. a. sabulosus (S side Scammon's Lagoon, Baja California*). Guerrero Negro (27.895556 N, 113.971667 W). Haplotype 4 (9337, HQ693909), haplotype 7 (1684, HQ690040), Haplotype 8 (9336, HQ690041). C. a. paralios (Barril lat $28^{\circ} 20^{\prime} \mathrm{N}$ on Gulf of California, Baja California*). El Barril (28.296389 N, 112.871556 W). Haplotype 5 (11628, 11629, 11632, 11633, HQ690037), haplotype 6 (11630, 11631, HQ690038). C. a. arenarius (San Jorge, near Comondú, Baja California [Sur]*). San Jorge (25.726111 N, 112.074167 W). Haplotype 9 (6743, HQ690042), haplotype 10 (6742, 6744, HQ690043), haplotype 11 (6745, HQ690044), haplotype 12 (6746, HQ690045), haplotype 13 (6748, HQ690046). C. a. albulus (Magdalena Island, Baja California [Sur]*). Isla Magdalena (24.346111 N, 112.154167 W). Haplotype 16 (5071, HQ690049), haplotype 17 (5943, 5088, 5934, 5935, 5936, 5937, 5938, 5941, HQ690050). C. a. ramirezpulidoi (El Mogote, Baja California Sur*). Mogote (24.166667 N, $110.350000 \mathrm{~W})$ haplotype 18 (158, 162, HQ690051), haplotype $19(171,163,174$, HQ690052), haplotype 20 (172, HQ690053), haplotype 21 (173, 175, HQ690054), haplotype 22 (168, HQ693908).

Chaetodipus siccus (Ceralbo [Cerralvo] Island, Baja California [Sur]*). Isla Cerralvo (24.161111 N, 109.863889 W). Haplotype $23(5600,5611,5613$, HQ690055), haplotype 24 (5601, 5603, HQ690056), haplotype 25 (5602, HQ690057), haplotype 26 (5604, HQ690058), haplotype 27 (5614, HQ690059), haplotype 28 (5616, 230, 231, 233, 234, 235, 5594, 15280, HQ690060), haplotype 29 (5617, HQ690061), haplotype 30 (15279, HQ690062).

Chaetodipus dalquesti ammophilus (Santa Margarita Island, Baja California Sur). Isla Margarita (24.406778 N, $111.823111 \mathrm{~W})$. Haplotype 14 (5950, 5951, 5952, 5954, 5959, 5961, HQ690047), haplotype 15 (5953, 5962, HQ690048). C. d. sublucidus (La Paz, Baja California [Sur]*). La Paz (24.137583 N, 110.467361 W). Haplotype 31 (252, HQ690063), haplotype 32 (254, HQ690064), haplotype 33 (255, HQ690065), haplotype 34 (1925,
HQ690066), haplotype 35 (1926, HQ690067), haplotype 36 (1927, HQ690068), haplotype 37 (1928, HQ690069), haplotype 38 (1931, HQ690070). C. d. dalquesti (4 mi SE Migriño (32 km SSE Todos Santos), Baja California Sur,

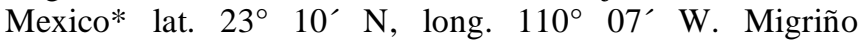
(23.740000 N, 110.200556 W). Haplotype 39 (13039, HQ693907), haplotype 40 (6978, HQ690071), haplotype 41 (6979, HQ690072), haplotype 42 (6980, HQ690073), haplotype 43 (6981, HQ690074), haplotype 44 (13172, HQ690075). Outgoup: Chaetodipus baileyi (HQ690076), Chaetodipus rudinoris (HQ690077) Chaetodipus spinatus (HQ690078).

\section{APPENDIX 2}

Specimens examined of Heteromys and Liomys including localities with altitude (m), latitude and longitude, and haplotype number (voucher and GenBank accession number in parentheses). All specimens are housed in the mammals collection of El Colegio de la Frontera Sur in San Cristóbal de Las Casas (ECO-SC-M), except specimens indicated with CIB which are housed in the Centro de Investigaciones Biológicas del Noroeste.

Heteromys d. desmarestianus. Chiapas: $100 \mathrm{~m}$ SE Ejido Loma Bonita, 232 m (16.19400 N, 91.30999 W), haplotype 7 (1306, GU681750; 1360, GU681774). Cerro Chipote: 1.77 Km al S Ejido Loma Bonita, 600 m (16.18379 N, 91.31109 W), haplotype 6 (1521, HQ693910), haplotype 7 (1532, HQ693911). RIBMA, enfrente del Ejido Playón de la Gloria, $180 \mathrm{~m}(16.18239 \mathrm{~N}, 90.92569 \mathrm{~W})$, haplotype 7 (1873, GU681749; 2075, GU681752; 2076, GU681747).

Heteromys d. goldmani. Chiapas: Ejido Ojo de Agua: 5.6 Km al SE de Bellavista, 2150 m (15.59809 N, 92.29419 W), haplotype 1 (1612, HQ693912; 1970, GU681753; 1971, GU681751; 1973, GU681757), haplotype 3 (1613, GU681771; 1616, GU681759), haplotype 5 (1968, GU681754). Finca Irlanda: $26 \mathrm{~km}$ por carretera a Nueva Alemania, al NW de Tapachula, 1095 (14.92879 N, $92.28399 \mathrm{~W})$, haplotype 1 (1831, GU681734; 1832, GU681755), haplotype 2 (1833, HQ693913), haplotype 4 (1830, GU681756).

Heteromys gaumeri. Quintana Roo: El Eden, $25 \mathrm{Km}$ al NNE de Leona Vicario, 10 m (21.21699 N, 87.18299 W), haplotype 9 (2056, GU681746). Reserva El Eden. $23 \mathrm{Km}$ al $\mathrm{N}$ de Leona Vicario, $10 \mathrm{~m}(21.21450 \mathrm{~N},-87.18419 \mathrm{~W})$, haplotype 9 (2061, GU681743). Yucatán: Km 12 carretera Ticul-Muna, $20 \mathrm{~m}$ (20.44750 N, -89.62889 W), haplotype 8 (CIB 5451, GU681748), haplotype 11 (CIB 5449, GU681745). Rancho Hobonil, $2.5 \mathrm{~km} \mathrm{~N}, 1 \mathrm{Km} \mathrm{W}$ de Tzucacab, $37 \mathrm{~m}$ (20.01600 N, 89.01999 W), haplotype 10 (2245, HQ693914). Campeche: Ejido Río Caribe $49 \mathrm{Km}$ por carretera de Candelaria, $81 \mathrm{~m}(18.19799$ N, 90.54199 W), haplotype 8 (3170, HQ693915).

Heteromys nelsoni. Chiapas: Cerro Mozotal: $30 \mathrm{~km}$ al N de Motozintla por carretera Buenos Aires- El Porvenir, 2820 m $(15.42549 \mathrm{~N}, 92.34069 \mathrm{~W})$, haplotype 12 (1906, GU681763; 1917, GU681760; 1922, GU681761; 1943, GU681758; 1945, HQ693916), haplotype 13 (1918, GU681762). 1.2 Km del desvio de terraceria a la Comunidad 
La Cascada, 2850 m (15.42599 N, 92.33399 W), haplotype 12 (2403, HQ693917).

Liomys pictus. Oaxaca: Rancho Don Pedro: $3.18 \mathrm{~km} \mathrm{NW}$ de Montecillo Santa Cruz, 6 m (16.38800 N, 94.60900 W), 2639, HQ693918. Chiapas: Rancho San Isidro, $420 \mathrm{~m}$ (16.53899 N, 92.80599 W), 2047, HQ693919.

Liomys salvini. Chiapas: Comunidad El Cerrón, $8.33 \mathrm{Km} \mathrm{NE}$ de Pijijiapan, $240 \mathrm{~m}(15.74300 \mathrm{~N}, 93.15100 \mathrm{~W}), 1992$, HQ693920. 3.95 Km NW del Faro de Puerto Arista, $20 \mathrm{~m}$ (15.95100 N, 93.82499 W), 967, HQ693921.

\section{CONFLICT OF INTEREST}

None declared.

\section{REFERENCES}

[1] Mittermeier RA, Myers N, Thomsen JB, da Fonseca GAB, Olivieri S. Biodiversity hotspots and major tropical wilderness areas: approaches to setting conservation priorities. Conserv Biol 1998; 12: 516-20.

[2] Ramamoorthy TP, Bye R, Lot A, Fa J. The biological diversity of Mexico: origins and distribution. Oxford University Press, New York 1998.

[3] Swift CC, Findley LT, Ellingson RA, Flessa KW, Jacobs DK. The Delta Mudsucker, Gillichthys detrusus, a valid species (Teleostei: Gobiidae) endemic to the Colorado River Delta, Northernmost Gulf of California, Mexico. Copeia 2011; 1: 93-102.

[4] Hafner MS, Light JE, Hafner DJ, Brant SV, Spradling TA, Demastes JW. Cryptic Species in the Mexican Pocket Gopher Cratogeomys merriami. J Mamm 2005; 86: 1095-108.

[5] Hajibabaei M, Singer GAC, Clare EL, Hebert PDN. Design and applicability of DNA arrays and DNA barcodes in biodiversity monitoring. BMC Biol 2007; 5: 24.

[6] Wilson DE, Reeder DM. Mammal species of the world: a taxonomic and geographic reference. 3rd edition. Smithsonian Institution Press, Washington, D.C. 2005.

[7] Álvarez-Castañeda ST. Analysis of the antelope ground squirrel (Ammospermophilus leucurus) of the Baja California peninsula and Gulf of California islands. J Mamm 2007; 88:1160-9.

[8] Álvarez-Castañeda ST. Rios E. A phylogenetic analysis of Neotoma varia (Rodentia: Cricetidae), a rediscovered, endemic, and threatened rodent from Datil Island, Sonora, Mexico. Zootaxa 2010; 2647: 51-60.

[9] Lorenzo C. Álvarez-Castañeda ST, Vázquez J. Conservation status of the threatened insular San Jose brush rabbit (Sylvilagus mansuetus). Western North American Naturalist 2011; 71: 10-6.

[10] Baker RJ, Bradley RD. Speciation in mammals and the Genetic Species Concept. J Mamm 2006; 87: 643-62.

[11] Borisenko AV, Lim BK, Ivanova NV, Hanner RH, Hebert PDN. DNA barcoding in surveys of small mammal communities: a field study in Suriname. Mol Ecol Res 2008; 3: 471-9.

[12] Clare E, Lim BK, Engstrom MD, Eger JL, Hebert PDN. DNA Barcoding of Neotropical bats: species identification and discovery within Guyana. Mol Ecol Notes 2007; 7: 184-90.

[13] Patton JL, Huckaby DG, Álvarez-Castañeda ST. The systematic and evolutionary history of woodrats of the Neotoma lepida complex. Univ Cal Press 2007; 135: 1-411.

[14] Álvarez-Castañeda ST. Systematics of the antelope ground squirrel (Ammospermophilus) from islands adjacent to the Baja California peninsula. J Mamm 2009; 88: 1160-9.

[15] Patton JL, Álvarez-Castañeda ST. Family Heteromyidae. Pp. 351443. in: Mamíferos del Noroeste de Mexico (Álvarez-Castañeda ST, Patton JL, eds.) Centro Invest Biol Noroeste, La Paz, BCS. Mexico 1999

[16] Williams DF, Genoways HH, Braun JK. Taxonomy and systematics. in: Biology of the Heteromyidae (Genoways $\mathrm{HH}$, Brown JH, eds.). Special publications No. 10, Amer Soc Mamm 1993; 38-197.

[17] Roth EL. A new species of pocket mouse (Perognathus: Heteromyidae) from the Cape Region of Baja California Sur, Mexico. J Mamm 1976; 57: 562-6.
[18] Álvarez-Castañeda ST. Analysis of the nomenclature and taxonomy of the species of mammals of the Baja California Peninsula. J Arizona-Nevada Acad Sci 1998; 22: 57-70.

[19] Lackey JA. Chaetodipus arenarius. Mamm Species 1991; 384: 1-4.

[20] Álvarez-Castañeda ST, Cortés-Calva P. A new subespecies of sand pocket mouse Chaetodipus arenarius (Rodentia: Heteromyidae) from Baja California Sur, Mexico. Pp. 33-40. In Homenaje a la trayectoria Mastozoológica de José Ramírez Pulido (Castro Campillo A. y J. Ortega eds.). Universidad Autónoma Metropolitana, Iztapalapa, pp. 248, México 2004.

[21] Álvarez-Castañeda ST, Rios E. Revision of Chaetodipus arenarius. Zool J Linnean Soc 2011; 161: 213-28.

[22] Anderson RP, Jarrín-VP. A new species of spiny pocket mouse (Heteromyidae: Heteromys) endemic to western Ecuador. Amer Mus Novit 2002; 3382: 1-26.

[23] Anderson RP. Taxonomy, distribution, and natural history of the genus Heteromys (Rodentia: Heteromyidae) in western Venezuela, with the description of a dwarf species from the Península de Paraguaná. Amer Mus Novit 2003; 3396: 1-43.

[24] Anderson RP, Weksler M, Rogers DS. Phylogenetic analyses of spiny pocket mice (Heteromyidae:Heteromyinae) based on allozymic and morphological data. J Mamm 2006; 87: 1218-33.

[25] Anderson RP, Timm RM. A new montane species of spiny pocket mouse (Rodentia: Heteromyidae: Heteromys) from northwestern Costa Rica. Amer Mus Nov 2006; 3509: 1-38.

[26] Reid FA. A field guide to the mammals of Central America and Southeast Mexico. Oxford University Press, Inc. New York. 1997.

[27] Rogers DS, Schmidly DJ. Systematics of spiny pocket mice (genus Heteromys) of the desmarestianus species group from Mexico and northern Central America. J Mamm 1982; 63: 375-86.

[28] Rogers DS. Genic evolution, historical biogeography, and systematic relationships among spiny pocket mice (subfamily Heteromyinae). J Mamm 1990; 71: 668-85.

[29] Rogers DS, Rogers JE. Heteromys nelsoni. Mamm Species 1992 ; 397: 1-2

[30] Cuarón A, Reid F, Vázquez E. Heteromys nelsoni. in: IUCN 2009 IUCN Red List of Threatened Species. Version 2009.2 <www.iucnredlist.org>. Downloaded on 11 July 2009.

[31] Rogers DS. Evolutionary implications of chromosomal variation among spiny pocket mice, genus Heteromys (order Rodentia) Southwestern Nat 1989; 34: 85-100.

[32] IUCN Red List of Threatened Species. Version 2009.1. (www.iucnredlist.org). [Downloaded on 11 July 2009].

[33] SEMARNAT (Secretaría de Medio Ambiente, Recursos Naturales y Pesca). Norma Oficial Mexicana NOM-059-SEMARNAT-2001. Protección ambiental- especies nativas de Mexico de flora y fauna silvestres- categorías de riesgo y especificaciones para su inclusión, exclusión o cambio- lista de especies en riesgo. Diario Oficial de la Federación 2002. 1: 1-153

[34] Lorenzo C. Sistemática molecular y filogeografía de roedores heterómidos (Rodentia: Heteromyidae) en el sureste de Mexico. Final Report. Project 80461. Fondo Sectorial de Investigación para la Educación Investigación Básica. Consejo Nacional de Ciencia y Tecnología- Secretaría de Educación Pública. 2010.

[35] Rogers DS, Gonzalez MW. Phylogenetic relationships among spiny pocket mice (Heteromys) inferred from mitochondrial and nuclear sequence data. J Mamm 2010; 91: 914-30.

[36] Aljanabi SM, Martinez I. Universal and rapid salt-extraction of high quality genomic DNA for PCR-based techniques. Nucleic Acids Res 1997; 25: 4692-3.

[37] Ivanova NV, Zemlak ST, Hanner RH, Hebert PDM. Universal primer cocktail for fish DNA barcoding. Mol Ecol Res 2007; 7: 544-548.

[38] Posada D. Collapse ver. 1.1. 2004. Available from http://darwin.uvigo.es/software/collapse.html. [Downloaded on 20 June 2010].

[39] Clement M, Posada D, Crandall K. TCS: a computer program to estimate gene genealogies. Mol Ecol 2000; 9: 1657-1660.

[40] Nylander JAA. MrModeltest version 2.2. Program distributed by the author. Evolutionary Biology Center. Uppsala University, Sweden. 2004

[41] Swofford DL. PAUP*: phylogenetic analysis using parsimony (* and other methods). Version 4.0b10. Sinauer Associates, Inc., Publishers, Sunderland, Massachusetts. 2002.

[42] Ronquist F, Huelsenbeck JP. Mrbayes3: Bayesian phylogenetic inference under mixed models. Bioinformatics 2003; 19: 1572-4. 
[43] Schneider S, Kueffer JM, Roessli D Excoffier L. ARLEQUIN ver. 2.000. A software for population genetic data analysis. Genetics and Biometry Laboratory, University of Geneva, Switzerland. 2000.

[44] Bradley RD, Baker RJ. A test of genetic species concept: cytochrome- $b$ sequence and mammals. J Mamm 2001; 84: 960-73.
[45] de Queiroz K, Donoghue MJ. Phylogenetic systematics or Nelson's version of cladistics? Cladistics 1990, 6: 61-75.

[46] Espinoza J. Variación geográfica en la morfológica de Heteromys desmarestianus en Chiapas, Mexico. Tesis Licenciatura en Biología. Instituto Tecnológico del Valle de Oaxaca, Xoxocotlán, Oaxaca, 2010.

() Álvarez-Castañeda; Licensee Bentham Open.

This is an open access article licensed under the terms of the Creative Commons Attribution Non-Commercial License (http://creativecommons.org/licenses/by-nc/3.0/) which permits unrestricted, non-commercial use, distribution and reproduction in any medium, provided the work is properly cited. 